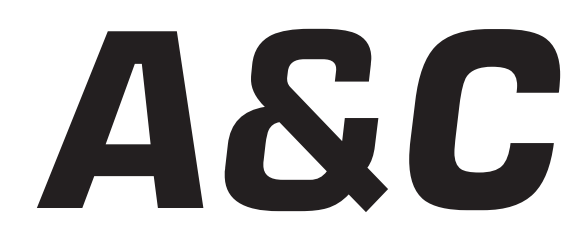

Revista de Direito Administrativo \& Constitucional

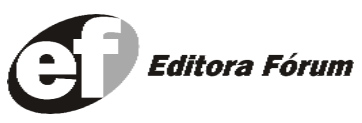

A\&C R. de Dir. Administrativo e Constitucional, Belo Horizonte, ano 5, n. 21, p. 1-252, jul./set. 2005 


\section{A\&C REVISTA DE DIREITO ADMINISTRATIVO E CONSTITUCIONAL}

\section{IPDA}

Instituto Paranaense

de Direito Administrativo

Direção Geral

Romeu Felipe Bacellar Filho

Direção Editorial

Paulo Roberto Ferreira Motta

Direção Executiva

Emerson Gabardo

Conselho de Redação

Edgar Chiuratto Guimarães

Adriana da Costa Ricardo Schier

Célio Heitor Guimarães

Conselho Editorial

Adilson Abreu Dallari

Alice Gonzáles Borges

Carlos Ari Sundfeld

Carlos Ayres Britto

Carlos Delpiazzo

Cármen Lúcia Antunes Rocha

Celso Antônio Bandeira de Mello

Clèmerson Merlin Clève

Clóvis Beznos

Enrique Silva Cimma

Eros Roberto Grau

Fabrício Motta

Guilhermo Andrés Muñoz (in memoriam)

Jaime Rodríguez-Arana Muñoz

Jorge Luís Salomoni
José Carlos Abraão
José Eduardo Martins Cardoso

José Luís Said

José Mario Serrate Paz

Juan Pablo Cajarville Peruffo

Juarez Freitas

Julio Rodolfo Comadira

Luís Enrique Chase Plate

Lúcia Valle Figueiredo

Manoel de Oliveira Franco Sobrinho

(in memoriam)

Marçal Justen Filho

Marcelo Figueiredo

Márcio Cammarosano

Maria Cristina Cesar de Oliveira
Nelson Figueiredo

Odilon Borges Junior

Pascual Caiella

Paulo Eduardo Garrido Modesto

Paulo Henrique Blasi

Paulo Neves de Carvalho (in memoriam)

Paulo Ricardo Schier

Pedro Paulo de Almeida Dutra

Regina Maria Macedo Nery Ferrari

Rogério Gesta Leal

Rolando Pantoja Bauzá

Sérgio Ferraz

Valmir Pontes Filho

Yara Stropa

Weida Zancaner

\footnotetext{
A246 A\&C Revista de Direito Administrativo e Constitucional. ano 3, n. 11, jan./mar. 2003. Belo Horizonte: Fórum, 2003.

Trimestral

ano 1, n.1, 1999 até ano 2, n.10, 2002 publicada pela Editora Juruá em Curitiba

ISSN: 1516-3210

1. Direito Administrativo. 2. Direito Constitucional. I. Fórum.
}

CDD: 342 CDU: 33.342

(c) Editora Fórum Ltda. 2005

Todos os direitos reservados. É proibida a reprodução total ou parcial, de qualquer forma ou por qualquer meio eletrônico ou mecânico, inclusive através de processos xerográficos, de fotocópias ou de gravação, sem permissão por escrito do possuidor dos direitos de cópias (Lei $n^{\circ}$ 9.610, de 19.02.1998).

Editora Fórum Ltda

Av. Afonso Pena, 2770 - 15\%16ªndar - Funcionários

CEP 30130-007 - Belo Horizonte/MG - Brasil

Tel.: 08007043737

Internet: www.editoraforum.com.br

e-mail: editoraforum@editoraforum.com.br
Editor responsável: Luís Cláudio Rodrigues Ferreira Projeto gráfico e diagramação: Luis Alberto Pimenta Revisora: Olga M. A. Sousa

Pesquisa jurídica: Fátima Ribeiro - OAB/MG 74868

Bibliotecária: Nilcéia Lage de Medeiros

CRB 1545/MG 6a região

Os conceitos e opiniões expressas nos trabalhos assinados são de responsabilidade exclusiva de seus autores.

Impressa no Brasil / Printed in Brazil

Distribuída em todo Território Nacional 


\title{
O Princípio do Equilíbrio Econômico- Financeiro em face das Transformações do Regime Jurídico Administrativo
}

\author{
Cristiane Schwanka \\ Bacharel em Direito formada pela UNIBRASIL. Engenheira Civil, especialista em gerenciamento \\ de obras pelo CEFET/PR
}

\begin{abstract}
Resumo: O texto propõe uma análise do tema do equilíbrio econômicofinanceiro dos contratos administrativos com ênfase à necessidade da sua manutenção, conforme determina o texto constitucional, propondo uma nova leitura em razão das modificações que se operam no regime jurídico administrativo em face da atual conformação do Estado. Destaca que a intensificação das relações da Administração Pública com os particulares, decorrente, principalmente, da maior atuação desses em atividades antes exclusivas do Estado, reclama modificações nos institutos tradicionais do regime jurídico administrativo com vistas a obter maior colaboração do particular na busca do bem comum. Assim, se a Administração pública pretende a manutenção ou incremento dessa colaboração, deve garantir ao particular maior segurança jurídica na relação contratual. Nesse aspecto, a preservação do princípio do equilíbrio econômico-financeiro do contrato, que nada mais é do que a preservação do valor pactuado no contrato com o intuito de manter uma relação de equilíbrio da atividade contratada em face do encargo financeiro correspondente ganha crucial importância. Neste trabalho se buscará, a partir de uma análise doutrinária, propor algumas reflexões sobre a possibilidade de utilização de meios consensuais para a solução dos conflitos em contratos celebrados sob a incidência do regime jurídico administrativo, com destaque para a transação e a arbitragem.
\end{abstract}

Palavras-chave: equilíbrio econômico-financeiro - contratos administrativos - regime jurídico administrativo - discricionariedade - solução de conflitos - consensualismo - transação - arbitragem - Constituição Federal - código eleitoral - eleições

Sumário: Introdução - 1 A conformação da administração pública consensual - 1.1 A consensualidade e o equilíbrio econômico-financeiro nos contratos administrativos - 1.2 Segurança jurídica para o particular como agente colaborador da administração pública - 1.3 A possibilidade da transação e arbitragem nos contratos administrativos - Considerações finais - Referências bibliográficas

\section{Introdução}

Dispõe a Lei $\mathrm{n}^{\circ}$ 8.666/93, nas hipóteses de o contrato administrativo ter sido alterado, sobre a possibilidade de acordo de vontades para restabelecer o pactuado inicialmente, ou seja, a equação econômicofinanceira do contrato, como avençada. $\mathrm{O}$ fundamento de tal recomposição é a proteção do interesse público subjacente ao contrato, a fim de que A \& C R. de Dir. Administrativo e Constitucional, Belo Horizonte, ano 5, n. 21, p. 99-117, jul./set. 2005 
esse seja integralmente cumprido. Ao particular contratado cabe a prova inequívoca do ônus econômico a maior, bem como a demonstração técnica de tal ônus, com a finalidade de tornar possível a avaliação e reparação por parte da Administração. Quando a Administração compensa o contratado pelos aumentos de custos que enfrenta, não está, propriamente, assumindo os prejuízos deste. Afinal, ao colaborar com o Estado através de um contrato, ele está assumindo uma atividade (e os correlatos riscos) que o Estado teria de desempenhar, se agisse sem colaboração. Sem a recomposição necessária, muitas vezes, o particular não dispõe de numerários suficientes para a conclusão da obra ou serviço contratado. O Direito busca estabelecer um equilíbrio entre as pretensões concorrentes e antagônicas: o lucro almejado pelo particular e o atendimento ao interesse público, por isso a existência dessa autorização legislativa que confere à Administração poderes para transacionar e resolver de forma consensual o conflito instaurado.

As fórmulas tradicionais de solução de conflitos no âmbito administrativo e a revalorização do indivíduo como figura central da vida do Estado impulsionam o desenvolvimento de uma nova dimensão do fenômeno de participação na sociedade contemporânea. O efeito da moderna concepção do "Estado Sociedade" se traduz na não rigorosa separação do Estado e do Cidadão, mas em recíproca coordenação, como incentivo ao espírito de colaboração e de pacífica coexistência e participação. A idéia da consensualidade vem sendo incorporada à Administração Pública como alternativa à imperatividade e à unilateralidade para despertar o entusiasmo e o desejo de colaboração do particular, na medida em que acena com a rápida superação dos conflitos e assegura maior estabilidade nas relações administrativas. Os modelos autoritários de execução da função administrativa, inúmeras vezes transformam os contratantes em adversários, não reconhecendo os administrados como parceiros; colaboradores que pretendem ter um com o outro, uma relação de interesses equilibrados, através da celebração de um instrumento de cooperação segundo os ditames da fraternidade e justiça no interesse de ambos e da própria sociedade.

A implementação de mecanismos que visem à pacificação de conflitos através de modos alternativos para solução de controvérsias, tais como, técnicas de transação e arbitragem, institutos plenamente aplicáveis no âmbito do Direito privado, inicia sua incursão no campo do regime 
jurídico direito público, ainda com muito debate doutrinário acerca da matéria. Entre eles, destaca-se a discussão acerca da viabilidade jurídica da implementação do instituto da arbitragem nos contratos administrativos, como meio de composição de controvérsias instaladas apenas entre as partes do contrato.

\section{A conformação da administração pública consensual}

A alteração da fisionomia do tradicional Direito Administrativo autoritário, delineado pela pouca atenção conferida aos direitos e garantias integrantes do patrimônio do cidadão modificou-se neste final do século XX. ${ }^{1}$ A Constituição Federal de 1988 consolidou o regime jurídico constitucional-administrativo com a disposição expressa dos princípios da legalidade, impessoalidade, moralidade, publicidade e, posteriormente, da eficiência. Essa conformação, decorrente da supremacia da Constituição, impõe que a interpretação da totalidade do Direito administrativo seja realizada conforme os princípios constitucionais. ${ }^{2}$ A participação de particulares do segundo setor na esfera da Administração Pública, que pode implicar diferentes formas de colaboração, em regra, assenta-se numa contradição: enquanto o particular procura o lucro, a Poder Público busca a satisfação de uma necessidade coletiva. ${ }^{3}$

A índole das relações entre particular e Administração deve se assentar no respeito mútuo de interesses, porém, os mecanismos de operacionalização da participação do privado no âmbito da Administração vêm apresentando insuficiências e contradições. Nesse sentido, adverte Paulo Modesto que "o aparato jurídico é incapaz de induzir a participação popular; mais ainda, freqüentemente cumpre papel inverso, dificultando a participação, estabelecendo mecanismos de neutralização e acomodação extremamente sutis." ${ }^{4}$ [grifos do autor] Em outras palavras, porém com singular entendimento, Patrícia Baptista declara que o Direito administrativo encontra-se desatualizado e inadaptado às novas formas de execução das atividades públicas que vieram com o Estado-providência. ${ }^{5}$ As funções e responsabilidades que a sociedade demanda exigem atualização permanente da Administração, não como um processo acabado, mas em

1 BACELLAR FILHO, Romeu Felipe. Processo Administrativo Disciplinar. São Paulo: Max Limonad, 2003, p. 21.

2 Ibid., p. 27.

3 MELLO, Celso Antonio Bandeira de. Curso de Direito Administrativo. 17. ed. rev., atual. São Paulo: Malheiros, 2004, p. 595.

4 MODESTO, Paulo. Participação Popular na Administração Pública: Mecanismos de Operacionalização. Revista Diálogo Jurídico., Salvador, v. 1, n. 7, out. 2001. Disponível em: <htpp://www. Direitopublico.com.br/sumario/asp >. Acesso em: 29 jul. 2004.

5 BAPTISTA, Patrícia. Transformações do Direito Administrativo. Rio de Janeiro: Renovar, 2003, p. 17. 
contínua adaptação. ${ }^{6}$

Tradicionalmente, tende a ser considerada inviável a admissão da via de natureza consensual na Administração Pública, a quem cabe, quase que exclusivamente, a função de executar de forma objetiva a vontade fixada na lei, a qual não poderia ser objeto de negociação, ou ajuste. A partir do reconhecimento de que o Estado não consegue, sozinho, realizar sua extensa gama de tarefas públicas sem a colaboração dos particulares verifica-se uma reversão desta tendência, reduzindo-se o preconceito existente com relação às possibilidades de uma atuação administrativa não estritamente unilateral. Destaca Patrícia Baptista que "a Administração, feita para mandar, se deu conta de que o poder de mando em muitos casos não bastava, abrindo-se o caminho da negociação." Para a autora, as fórmulas tradicionais de solução de conflitos no âmbito administrativo e a revalorização do indivíduo como figura central da vida do Estado impulsionam o desenvolvimento de uma nova dimensão do fenômeno de participação na sociedade contemporânea. ${ }^{8}$ Sobre essa "mudança de eixo", iniciada após o segundo Pós-Guerra, destaca Baptista:

A configuração do Estado de Direito que emergiu daquele momento histórico levou o indivíduo para o centro das atenções da vida estatal e, em conseqüência, da vida administrativa. Da condição de súdito, de mero sujeito subordinado à Administração, o administrado foi elevado ao status de cidadão. Essa nova posição do indivíduo, amparada no desenvolvimento do discurso dos direitos fundamentais, demandou a alteração do papel tradicional da Administração Pública. Direcionada para o respeito à dignidade da pessoa humana, a Administração, constitucionalizada, vê-se compelida a abandonar o modelo autoritário de gestão da coisa pública para se transformar em um centro de captação e ordenação dos múltiplos interesses existentes no substrato social. Não pode, assim, prosseguir como um corpo autônomo em permanente oposição à sociedade, nem mesmo como um aparato decisório isolado, mas, ao contrário, deve funcionar como um espaço deliberativo para o desenvolvimento das potencialidades sociais. (...) No contexto dessa nova função administrativa, vocacionada para o respeito e concretização dos direitos fundamentais, a participação administrativa ganha papel de destaque (...) o cidadão consegue dialogar com a Administração. A participação administrativa representa, assim, em uma primeira acepção, o instrumento que torna possível ao indivíduo exercer influência em processos nos quais ele é afetado. ${ }^{9}$

O efeito da moderna concepção do "Estado Sociedade" se traduz na não rigorosa separação do Estado e do Cidadão, mas em recíproca coordenação, como incentivo ao espírito de colaboração e de pacífica ${ }^{6}$ MEDAUAR, Odete. O Direito Administrativo em Evolução. 2. ed. rev. atual. ampl. São Paulo: Revista dos Tribunais, 2003, p. 133.

7 BAPTISTA, op. cit., p. 264

8 BAPTISTA, op. cit., p. 120

9 BAPTISTA, op. cit., p. 129.

A \& C R. de Dir. Administrativo e Constitucional, Belo Horizonte, ano 5, n. 21, p. 99-117, jul./set. 2005 
coexistência e participação. ${ }^{10}$

Destaca Medauar que "o enfoque evolutivo do direito administrativo significa, sobretudo, o intuito do seu aprimoramento como técnica do justo e, por isso, da paz social." 11 A tradição de um comportamento fechado e hierarquizado da Administração não se coaduna com o caráter de colaborador que, cada vez mais, tem sido desempenhado pelo particular, motivo que, entre outros, justifica a busca de um aspecto não conflitual dessa relação e a conformação de um regime jurídico administrativo mais democrático. Nesse sentido, leciona Diogo de Figueiredo Moreira Neto:

A consensualidade vem se tornando, por isso, um princípio instrumental a ser aplicado com a mesma importância que se empregou, ainda se emprega e se empregará a tradicional imperatividade no atendimento do interesse público (...) A sociedade se reequilibra, recusa-se a aceitar a imposição do dirigismo e a fatalidade do Estado ético, quer repartir ou, pelo menos, condicionar o papel decisório, expandido o espaço público não estatal (...) Em conclusão, é neste contexto e ao influxo dessas tendências que se adensa um continum de colaboração entre a Sociedade e o Estado no qual as transferências de atividades estatais a entes da sociedade não devem ficar à mercê de preconceitos e de suspicácias ideológicas, pois estão destinadas a ser um dos fenômenos jusadministrativos mais relevantes e mais úteis ao desenvolvimento homogêneo de todos os setores e, por isso mesmo, mais demandantes de estudos sistemáticos e multidisciplinares. ${ }^{12}$ [grifos do autor]

A conformação de uma Administração Pública consensual pautada na busca do ponto ótimo, que apregoa a máxima efetivação da norma, surge, na atualidade, como alternativa para atendimento ao interesse público e as demandas sociais.

\subsection{A consensualidade e o equilíbrio econômico-financeiro nos contratos administrativos}

A escolha da via consensual, em substituição da imperativa, permite que seja encontrada a solução mais adequada ao atendimento da finalidade pública almejada. ${ }^{13}$ A utilização de meios consensuais pela Administração ganha relevância na medida em que se transforma em instrumento da participação dos particulares envolvidos e interessados nas decisões administrativas, possibilitando mais aceitação do que imposição, especialmente

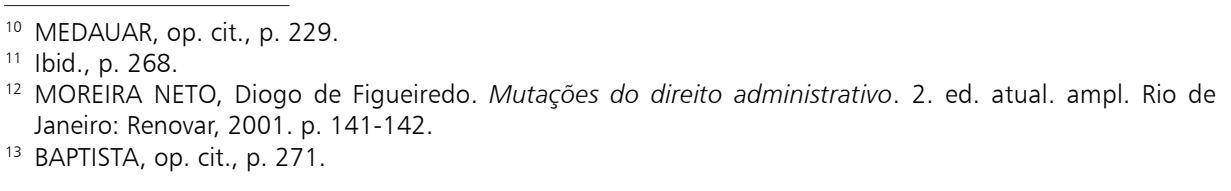

A \& C R. de Dir. Administrativo e Constitucional, Belo Horizonte, ano 5, n. 21, p. 99-117, jul./set. 2005 
no âmbito das relações contratuais administrativas. O contrato administrativo representa um vínculo de colaboração livre e remunerada do particular, que em associação com o Poder Público, visa realizar uma atividade que, originalmente, competiria à Administração. Assim, destaca Medauar, que "da Administração se exige que seja, ao mesmo tempo, transparente e eficaz; participativa e imparcial; legal e eficiente; as escolhas devem ser razoáveis, eqüitativas, baseadas no consenso dos destinatários e destinadas ao excelente rendimento." 14

Os contratantes, em vez de adversários, em um número cada vez maior de contratos, passam a ser caracterizados como parceiros, colaboradores que pretendem ter um com o outro, uma relação de interesses equilibrados, um instrumento de cooperação segundo os ditames da fraternidade e justiça no interesse de ambos e da própria sociedade. ${ }^{15} \mathrm{O}$ consenso que se formou entre as partes no momento da celebração do contrato não lhes permite, a qualquer uma delas, tirar vantagem além do que foi pactuado. ${ }^{16} \mathrm{~A}$ administração tem o dever de proceder em conformidade com o principio da moralidade e da boa-fé, como destaca Edílson Pereira Nobre Júnior:

Cabe, neste instante, perquerir o campo de movimentação da boa-fé na execução dos contratos celebrados pelo Poder Público. O primeiro ponto que ressai à vista concerne à preservação do equilíbrio econômico-financeiro do contrato. A posição equilibrada das partes no contrato administrativo aparece, nos últimos anos, como uma das preocupações mais sentidas do legislador. Mantendo tradição inaugurada pelo art. 167, II, da Constituição pretérita, o Constituinte de 1988, em duas passagens, consagrou tal ideal, Na primeira delas, fez de forma implícita, ao tratar do principio da moralidade, impeditivo do enriquecimento sem causa pela Administração. Na outra, de maneira inequívoca, figurou no art. 37, XXI, quando a pretexto de estatuir a obrigatoriedade da licitação, aludiu a cláusulas destinadas a estabelecer obrigações de pagamento, com a manutenção das condições efetivas da proposta. (...) A consagração constitucional e legal do equilíbrio econômico-financeiro dos contratos administrativos, de fundo moral, encontra, sem dúvida, respaldo no princípio que impõe à Administração agir segundo a boa-fé. ${ }^{17}$

A recomposição de preços necessária para o restabelecimento da equação econômico-financeira é, muitas vezes, condição para a mantença do contrato e, em regra, deve ser dar por alteração bilateral do contrato. ${ }^{18}$

14 MEDAUAR, op. cit., p. 133.

15 WALD, Arnold; MORAES, Luiza Rangel de et al. O Direito de Parceria e a Lei de Concessões. 2. ed. rev., atual. São Paulo: Saraiva, 2004, p. 37.

16 Id.

17 NOBRE JÚNIOR, Edílson Pereira. O Princípio da Boa-fé e sua Aplicação no Direito Administrativo Brasileiro. Porto Alegre: Sergio Antonio Fabris, 2002. p. 215. 
No contrato administrativo, uma vez verificado o rompimento do equilíbrio econômico-financeiro, o particular deve provocar a Administração para as providências adequadas ao seu restabelecimento. ${ }^{19}$ Ao discorrer sobre a dinamicidade da relação e a necessidade de manter vivo o vínculo contratual, destaca Arnold Wald:

\begin{abstract}
Atualmente, o contrato se transformou num bloco de direitos e obrigações de ambas as partes, que devem manter o seu equilíbrio inicial. Constitui, pois, um vínculo, ou até em uma entidade. Vínculo entre partes, por ser obra comum das mesmas, e entidade constituída por um conjunto dinâmico de direitos, faculdades, obrigações e eventuais outros deveres, que evolui de acordo com as circunstâncias que condicionam a atividade do contratante. Assim, em vez de um contrato irrevogável, fixo, cristalizado, que existia outrora, conhecemos um contrato dinâmico e flexível, que as partes devem adaptar para que ele possa sobreviver, superando as dificuldades encontradas no decorrer de sua existência. A plasticidade do contrato transforma a sua própria natureza, fazendo com que os interesses divergentes do passado sejam agora convertidos numa verdadeira parceria, na qual todos os esforços são válidos e necessários para fazer subsistir o vínculo entre os contratantes, respeitados evidentemente os direitos individuais. ${ }^{20}$
\end{abstract}

O restabelecimento da equação é realizado através de aditamento ao contrato, segundo Justen Filho, após a certificação, pela Administração, dos fatos alegados, examinando a situação originária (à época da apresentação das propostas) e a posterior e verificando se a relação original entre encargos e remuneração foi afetada. Em caso positivo, deverá alterarse a remuneração do contratado proporcionalmente à modificação de encargos. ${ }^{21}$ Considerando que o contrato administrativo carrega em seu bojo um interesse público a ser atendido, esse pode vir a não ser realizado se a Administração não conceder o restabelecimento da equação ou o fizer em desacordo com a proporção original entre encargos e a correspondente retribuição, implicando, inúmeras vezes em obras inacabadas e na descontinuidade do serviço público. A garantia de equilíbrio econômicofinanceiro baliza-se fundamentalmente pelo teor do contrato, que carrega consigo um interesse público. ${ }^{22}$ Nesse sentido, leciona Bandeira de Mello:

Tais soluções são obrigatórias em face de nosso Direito Positivo, visto que o art. 37, XXI, da Lei Magna do País estatui que obras e serviços (tanto quanto

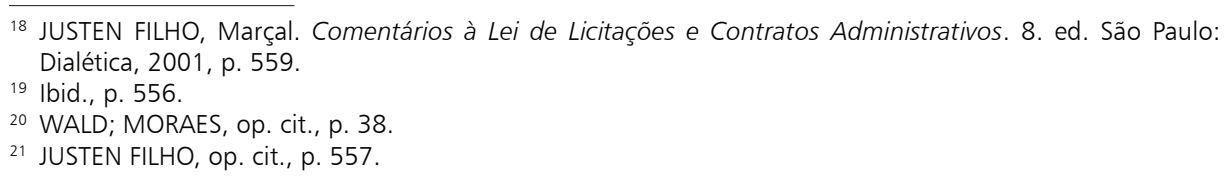

A \& C R. de Dir. Administrativo e Constitucional, Belo Horizonte, ano 5, n. 21, p. 99-117, jul./set. 2005 
compra e alienações) serão contratados "com cláusulas que estabeleçam obrigações de pagamentos mantidas as condições efetivas da proposta". (...) devem assegurar os termos econômicos que as partes assumiram ao compor o ajuste da equação econômico-financeira, traduzido na proposta aceita ao cabo da licitação. É que esta foi tida, por ambas as partes, como previsivelmente idônea para acobertamento dos custos em que correria o concessionário e suficiente para proporcionar-lhe a devida remuneração. ${ }^{23}$

As proteções conferidas ao particular, colaborador da Administração, são justificáveis por estar em causa vínculo no qual se consubstancia um interesse público. ${ }^{24} \mathrm{Na}$ solução do litígio administrativo, o contratado particular muitas vezes é tido como vilão pelo administrador, o que é completamente inadequado. O contratado, deve sim, ser considerado como um colaborador e não um adversário. A extensa e necessária colaboração do particular nas atividades administrativas, que pode ser desenvolvida no contexto do Estado Social, implica na necessidade de modificação da forma de relacionamento do Estado com o cidadão, retirando a arrogância e onipotência predominante para uma evolução necessária e justa, temperada pelo atendimento dos direitos dos contratantes e da segurança jurídica nas relações constituídas. ${ }^{25}$

\subsection{Segurança jurídica para o particular como agente colaborador da administração pública}

Os modelos autoritários de execução da função administrativa se tornaram incapazes de despertar o entusiasmo e o desejo de colaboração do particular. ${ }^{26}$ Conforme Alice Maria Gonzáles Borges, "a efetiva realização dos postulados do Estado Democrático de Direito é inseparável do mínimo direito dos cidadãos a serem governados por uma Administração Pública legal, segura e sobretudo, confiável". ${ }^{27}$ [grifo do autor] A idéia da consensualidade vem sendo incorporada à Administração Pública como alternativa à imperatividade e à unilateralidade, sendo que, de início apenas como uma técnica de administração e, posteriormente, como uma categoria do Direito administrativo. ${ }^{28}$ Ao discorres sobre as razões que podem ser apontadas em favor do consenso na atividade administrativa, Baptista

\footnotetext{
22 MELLO, op. cit., p. 689 .

23 MELLO, op. cit., p. 689 .

24 Id.

25 WALD; MORAES, op. cit., p. 46

26 BAPTISTA, op. cit., p. 264.
}

A \& C R. de Dir. Administrativo e Constitucional, Belo Horizonte, ano 5, n. 21, p. 99-117, jul./set. 2005 
destaca "que o interesse público tem condições de ser realizado com maior eficiência em um contexto de harmonia e, simultaneamente, com a satisfação dos interesses privados. (...) E, finalmente, na medida em que permite a superação dos conflitos, assegura maior estabilidade nas relações administrativas, aumentando o grau de segurança das partes envolvidas." ${ }^{29}$

Uma nova interação entre o cidadão e Administração, pelo aperfeiçoamento do canal de diálogo e daqueles voltados à tomada de decisão, na medida em que se tornam mais acessíveis e transparentes, propiciam maior estabilidade nas relações. Asseguram, em outras palavras, a tranqüilidade e a segurança de que ambas as partes contraentes poderão ver respeitados os seus legítimos direitos. Essa é a estabilidade que ambos os pólos da relação jurídica contratual perseguem: a segurança jurídica. Assim destaca Cármen Lúcia Antunes Rocha:

Segurança jurídica é o direito da pessoa à estabilidade em suas relações jurídicas. Este direito articula-se com a garantia da tranqüilidade jurídica que as pessoas querem ter, com a certeza de que as relações jurídicas não podem ser alteradas numa imprevisibilidade que as deixe instáveis e inseguras quanto ao seu futuro, quanto ao seu presente e até mesmo quanto ao seu passado. (...) Segurança jurídica firma-se como paládio de convicções e confiança. Se o direito não se afirma por seguro e garantidor da segurança para as pessoas, direito ele não é, pelo menos não como expressão maior da criação social e estatal. Por isto, segurança jurídica produz-se na confiança que se põe no sistema e na conviç̧ão de que ele prevalece e observa-se obrigatória e igualmente para todos. ${ }^{30}$

Nas relações jurídicas entre a Administração e os seus cidadãos esperase que o Estado comporte-se lealmente, em estrito respeito à palavra empenhada, nas condições em que foram estipuladas. Nesse sentido, enfatiza Juarez Freitas que “o Estado há de ser o primeiro, não o último, a observar as normas e zelar pela credibilidade da palavra dos que o representam." 11 Freqüentemente, Administrações mal orientadas, buscam tirar o máximo de vantagem nas contratações, à custa dos contratados, obrigando-os à recorrer à via judicial para obter o pagamento de seus créditos, legítimos, cuja demanda judicial pode levar anos para chegar à solução final, acar-

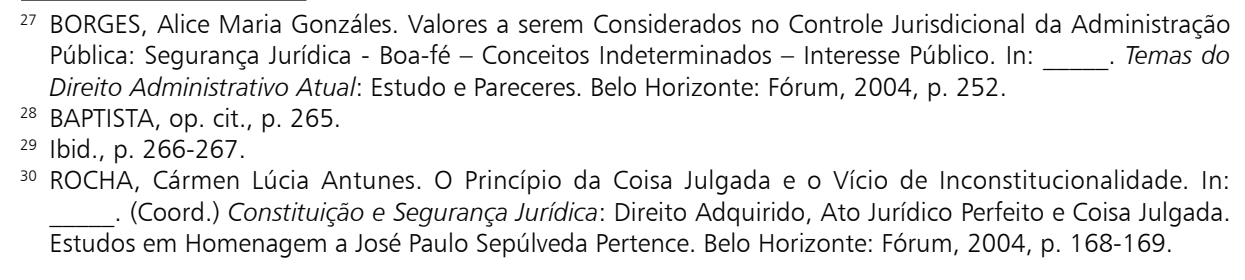


retando inúmeras vezes a ruína do colaborador. ${ }^{32}$ Esse procedimento, danoso e violador do princípio da boa-fé, é utilizado, freqüentemente, de forma autoritária e em nome da defesa dos interesses públicos. Nesse contexto, merece destaque a afirmação de Luísa Cristina Pinto e Netto:

Com estas constatações, é possível afirmar que a idéia de poder de autoridade não é indissociável do interesse público, a perseguição do interesse público pelo Estado não traz implícita a posição de superioridade jurídica deste. A peculiaridade da presença do Estado em relações jurídicas deve ser encontrada na finalidade perseguida, ou seja, na natureza do interesse que o Estado tem o dever de buscar e não no exercício de um poder de autoridade ou em pretensa supremacia. A Administração sempre deve perseguir o interesse público, usando ou não de poderes somente a ela conferidos pelo Direito. (...) por meio de relações consensuais em que a Administração comparece como colaboradora do particular também se busca a concretização do interesse público. ${ }^{33}$

Sem dúvida alguma, a efetiva realização dos ditames do Estado democrático de Direito é inseparável do respeito aos direitos do cidadão a ser governado por uma Administração justa, segura e confiável. ${ }^{34}$ Todavia, há de se ter presente que ao despir de seu caráter de unilateralidade e imperatividade, a Administração, na busca da cooperação, não pode implicar na negação de seu papel de tutora do interesse público e renunciar às prerrogativas que lhe são conferidas por esse fim. ${ }^{35}$ É preciso que o Estado mantenha a sua disposição todos os meios de concretização possíveis para que, se necessário, possa impor segundo as disposições legais, o interesse público sobre os privados que com ele não sejam compatíveis. ${ }^{36}$ A renúncia plena às prerrogativas conferidas pelo regime jurídico administrativo ao Poder Público poderia acarretar a submissão do Estado aos particulares que se tornariam cada vez mais fortes, em detrimento do interesse dos destinatários da atividade pública. ${ }^{37}$

\subsection{A possibilidade da transação e arbitragem nos contratos administrativos}

\footnotetext{
31 FREITAS, Juarez. O Controle dos Atos Administrativos e os Princípios Fundamentais. 3. ed. rev. ampl. São Paulo: Malheiros, 2004, p. 37.

32 BORGES, Alice Maria Gonzáles. O Princípio da Boa-fé nas Contratações Administrativas. In: do Direito Administrativo Atual: Estudo e pareceres. Belo Horizonte: Fórum, 2004, p. 189-191.

33 NETTO, Luisa Cristina Pinto e. Interesse Público e Administração Concertada. Revista de Direito Municipal., Belo Horizonte, v. 4, n. 7, p. 173-182, jan./mar. 2003, p. 179.

34 BORGES, op. cit., p. 192.

35 BAPTISTA, op. cit., p. 277.

36 NETTO, op. cit., p. 181
}

A \& C R. de Dir. Administrativo e Constitucional, Belo Horizonte, ano 5, n. 21, p. 99-117, jul./set. 2005 
Cada vez mais, no âmbito dos contratos administrativos, há a necessidade de implementação de mecanismos que visem à pacificação de conflitos através de modos alternativos para solução de controvérsias, com vistas a obter uma maior celeridade e especialidade na decisão, bem como apresentar uma resposta ao excessivo prolongamento dos tradicionais processos administrativos e judiciais. Para tanto, a doutrina administrativa tem discutido a implementação das técnicas consensuais de solução de conflitos, em especial a transação e a arbitragem, institutos plenamente aplicáveis no âmbito do Direito privado e que, com algumas ressalvas, ou impedimentos, iniciam sua incursão no campo do regime jurídico de Direito público.

O ordenamento jurídico brasileiro, de longa data, possibilita a solução de conflitos através da arbitragem, seja para dirimir disputas internacionais, como para solucionar matérias de Direito privado, especialmente, de Direito comercial. ${ }^{38}$ No entanto, sua consagração ocorreu com a promulgação da Lei de Arbitragem (Lei n 9.307/96), cujo art. $1^{\circ}$ dispõe que as pessoas capazes de contratar poderão valer-se da arbitragem para dirimir litígios relativos a direitos patrimoniais disponíveis. ${ }^{39}$ Já o artigo 25 estabelece que, sobrevindo no curso da arbitragem dissenso acerca de direito indisponível, o juízo arbitral remeterá as partes para o juízo competente. José Cretella Júnior conceitua o instituto da arbitragem como:

O sistema especial de julgamento, com procedimento, técnica e princípios informativos especiais e com força executória reconhecida pelo direito comum, mas a este subtraído, mediante o qual, duas ou mais pessoas físicas, ou jurídicas, de direito privado ou de direito público, em conflito de interesses, escolhem, de comum acordo, contratualmente, uma terceira pessoa, o árbitro, a quem confiam o papel de resolver-lhes a pendência, anuindo os litigantes em aceitar a decisão proferida. $^{40}$

No campo doutrinário, encontra-se em debate a viabilidade jurídica da arbitragem no âmbito dos contratos administrativos, alegando-se que

\footnotetext{
37 Nesse ponto, imprescindível é trazer à colação a advertência de Di Pietro: "No tema da parceria encontramse no direito brasileiro inúmeros exemplos de situações que ou são frontalmente ilegais ou, pelo menos, estão em zona fronteiriça com a ilegalidade e moralidade administrativa. Isto sempre em nome da eficiência. E é precisamente em nome dessa eficiência que tais situações vem sendo toleradas e mantidas." Cf. DI PIETRO, Maria Sylvia Zanella. Parcerias na administração pública. São Paulo: Atlas, 2002, p. 243.

38 O CPC, de 1939, já adotava a arbitragem, julgada compatível com a Constituição de 1946 - art. $141 \S 4^{\circ}$. Cf. SZKLAROWSKY, Leon Fredja. Uma Nova Visão da Arbitragem. Disponível em: < htpp://www1.jus.com.br/ doutrina/textos.asp >. Acesso em: 17 ago. 2004.

39 Do conceito de direitos patrimoniais disponíveis dependerá a aplicabilidade da lei de arbitragem às relações decorrentes de licitações que culminam com a celebração de contratos administrativos. Cf. VAZ, Isabel. Arbitragem, Licitação e livRe Concorrência. Revista de Direito Municipal, Belo Horizonte, v. 4, n. 7, p.173-182, jan./mar. 2003, p. 164.
} 
a Administração Pública não estaria autorizada, em virtude dos princípios da indisponibilidade e da supremacia do interesse público, a renunciar ao direito de recorrer ao Judiciário para dirimir suas controvérsias, bem como, que tal atitude implicaria em violação ao princípio da legalidade, tendo em vista que a solução arbitral pode, em tese, fundar-se por equidade. ${ }^{41}$ Sob tais argumentos, à primeira vista, o dispositivo da lei de arbitragem que condiciona sua aplicação à solução de questões referentes à direitos patrimoniais disponíveis parece afastar a possibilidade de sua aplicação nos litígios em que uma das partes seja o Estado. ${ }^{42}$

Todavia, já opera na esfera das relações contratuais administrativas, a solução amigável de controvérsias através da arbitragem, conforme discorre Leon Fredja Szklarowsky; ${ }^{43}$ "a Lei 8.987/95, que regula o regime de concessão e permissão de serviços públicos previstos no artigo 175 da CF, estabelece como cláusula essencial a que diz respeito ao foro e ao modo amigável de solução de divergências contratuais, aplicando-se a esses contratos administrativos também a Lei 8.666/93 (artigo $2^{\circ}$ )." ${ }^{44}$ [grifos do autor] A lei de concessão de serviço público, nesse dispositivo, está ampliando e esclarecendo o previsto no art. 54 da Lei $n^{\circ} 8.666 / 93,{ }^{45}$ sob a máxima proteção do manto constitucional, tendo em vista o disposto nos arts. 173, $\S 1^{\circ}$, II e 175 , parágrafo único, I da $\mathrm{CF} / 88 .{ }^{46}$ Ainda, o texto constitucional em seu art. 23, XV, determina serem cláusulas essenciais do contrato de concessão aquelas referentes ao foro e a modo amigável de solução das divergências contratuais. Nesse sentido, merece destaque a afirmação de Isabel VAZ: "Este dispositivo pode ser considerado uma evolução na análise

\footnotetext{
${ }^{40}$ CRETELLA JUNIOR, José. Da Arbitragem e seu Conceito Categorial. Revista de Informação Legislativa., Brasília, v. 25, n. 98, p. 127-138, abr./jun. 1998, apud MUNIZ, Tânia Lobo. Arbitragem no Brasil e a Lei 9.307/96. Curitiba: Juruá, 1999, p. 40.

41 WALD, Arnold; MORAES, Luiza Rangel de et al., op. cit., p. 268

${ }^{42}$ VAZ, Isabel. Arbitragem, Licitação e Livre Concorrência. Revista de Direito Municipal, Belo Horizonte, v. 4, n. 7, p. 173-182, jan./mar. 2003, p. 165.

43 O autor encaminhou ao então Vice-Presidente da República, Marcos Maciel, autor do projeto de lei que se transformou na Lei no 9.307 e ao professor Gilmar Ferreira Mendes, proposta visando acrescentar à Lei de Licitações e Contratos da Administração Pública - Lei nº 8.666/93 uma disposição semelhante à já existente na Lei $n^{\circ}$ 8.987/95, que trata do regime de permissão e concessão de Serviço Público (art. 23, XV), permitindo expressamente a solução das divergências contratuais e no âmbito das licitações, de forma amigável, através da arbitragem. O proposto dispositivo, norma geral, poderá ser inserido no lugar do parágrafo $4^{\circ}$, do artigo $3^{\circ}$ da citada Lei $n^{\circ}$ 8.666. Esse parágrafo fora vetado pelo Presidente da República e encontra-se ocioso, in verbis: $\mathrm{O}$ artigo $3^{\circ}$ da Lei $n^{\circ} 8.666 / 93$ fica acrescido do parágrafo $4^{\circ}$ : "No âmbito das licitações e nos contratos celebrados pela Administração Pública com pessoas físicas ou jurídicas, inclusive aquelas domiciliadas no estrangeiro, as divergências contratuais e sobre o certame licitatório poderão ser solucionadas, de forma amigável, por meio de arbitragem, contando com a presença de representante do contratante - Poder Público - e desde que prevista, no edital e no contrato." Cf. SZKLAROWSKY, Leon Fredja. A Arbitragem e a Administração Pública. Disponível em: <htpp:// www1.jus.com.br/doutrina/textos.asp>. Acesso em: 22 jul. 2004.

A \& C R. de Dir. Administrativo e Constitucional, Belo Horizonte, ano 5, n. 21, p. 99-117, jul./set. 2005 
da solução arbitral decorrente da observação dos fatos, da cultura jurídica e da convicção na seriedade e na celeridade da arbitragem." ${ }^{\prime 7}$ Nesse sentido, enfatiza Diogo de Figueiredo Moreira Neto que:

...o importante é ter-se patenteado um reconhecimento inequívoco da Lei, este sim, bem definido, de que há sempre um campo de interesses patrimoniais disponíveis dentro do qual a arbitragem não é apenas aceitável, mas recomendável como alternativa ao litígio judicial. E neste ponto reside a inovação oportuna e modernizadora introduzida pelo legislador brasileiro. ${ }^{48}$ [grifos do autor]

Ao admitir a arbitragem como solução amigável dos conflitos na esfera dos contratos administrativos ${ }^{49}$ Moreira Neto sustenta sua posição a partir da classificação de interesse público primário e secundário. Segundo o autor, não são possíveis solução arbitral situações que configurem a presença do interesse público primário, ${ }^{50}$ que, devido à sua relevância está fora do mercado, sendo, portanto, indisponível. Por outro lado, quando se verificar a presença de controvérsia que envolva os denominados interesses públicos secundários ${ }^{51} \mathrm{o}$ autor afirma que em virtude de seu caráter essencialmente patrimonial trata-se de interesse público disponível e que são, portanto, suscetíveis de transação e arbitragem, assim como todos os demais interesses e direitos derivados que possuam conotação patrimonial. E, ainda, enfatiza: "vale dizer, os que possam ser monetariamente quantificados e que estejam no comércio, sendo, usualmente, objeto de contratação, destinando-se a permitir à Administração satisfazer interesses finalísticos justificadores da própria existência do Estado." ${ }^{52}$ Nessa corrente, Odete Medauar destaca que,

45 Recentemente, o Conselho Especial do Tribunal de Justiça do Distrito Federal e dos Territórios, por unanimidade, reconheceu a possibilidade de adoção do juízo arbitral para dirimir questão contratual, conforme consta em uma parte da ementa: "III Pelo art. 54, da Lei no 8.666/93, os contratos administrativos regem-se pelas suas cláusulas e preceitos de direito público, aplicando-se-lhes, supletivamente, os princípios da teoria geral dos contratos e as disposições de direito privado, o que vem reforçar a possibilidade de adoção do juízo arbitral para dirimir questões contratuais." (Mandado de Segurança n 1998002 003066-9, julgado a 18 de maio de 1999). Cf. VAZ, Isabel. Arbitragem, Licitação e Livre Concorrência. Revista de Direito Municipal, Belo Horizonte, v. 4, n. 7, p. 173-182, jan./mar. 2003, p. 169

46 LEMES, Selma M. Ferreira. Arbitragem na Concessão de Serviços Públicos: Arbitrabilidade Objetiva, Confidencialidade ou publicldade Processual. Disponível em: <htpp://www1.jus.com.br/doutrina/ textos.asp >. Acesso em: 22 jul. 2004.

47 VAZ, op. cit., p. 166.

48 MOREIRA NETO, Diogo de Figueiredo. Arbitragem nos Contratos Administrativos. Revista de Direito Administrativo.,Rio de Janeiro, n. 209, p. 91-104, jul./set. 1997, p. 94

${ }^{49} \mathrm{Em}$ sentido contrário, afirmando a necessidade de existência de lei específica para que sociedade de economia mista de serviço público possa se submeter à arbitragem, ver Parecer de Luis Roberto Barroso. In: BARROSO, Luís Roberto. Temas de Direito Constitucional. Rio de Janeiro: Renovar, 2002. t. 2, p. 593-636.

50 Para o autor, o interesse público primário é aquele relacionado à segurança e ao bem estar da sociedade, competindo ao Estado satisfazê-lo por meio de regime próprio. Cf. MOREIRA NETO, op. cit., p. 94.

51 Para o autor, o interesse público secundário é aquele que possui natureza instrumental, existindo apenas para permitir a satisfação dos interesses primários, resolvendo-se em direitos patrimoniais e são, portanto, disponíveis. Cf. MOREIRA NETO, op. cit., p. 94. 
hodiernamente, "a supremacia do interesse público dá lugar à máxima realização dos interesses envolvidos como fundamento e como fim da atividade administrativa." ${ }^{53}$ [grifos do autor]

Quando o Estado, participa de relações contratuais privadas, não se pode sustentar que tenha ocorrido a disponibilidade do interesse público ou que esse tenha sido colocado em condição de inferioridade, pelo contrário, a utilização da forma contratual privada pode estar a representar uma mais eficiente e adequada busca do interesse público. Assim, destaca Luisa Cristina Pinto e Netto que "se assim é nos contratos privados, com mais razão o mesmo se verifica nos contratos administrativos, que, sujeitos a regime jurídico de direito Público, destinam-se direta e especificamente ao atendimento do interesse público. ${ }^{54} \mathrm{Na}$ mesma esteira são as recomendações de Selma M. Ferreira Lemes: ${ }^{55}$

Os contratos administrativos, ainda que não se refiram à concessão de serviços públicos, a teor do artigo 54 da Lei $n^{\circ} 8.666 / 93$, devem enaltecer a solução arbitral, a bem do interesse público. A boa e oportuna administração da Justiça, pelo Judiciário devem priorizar as questões que não digam respeito a direitos patrimoniais disponíveis, bem como é papel do Estado e de suas empresas públicas e sociedades de economia mista envidar esforços neste sentido, além de dar o exemplo à sociedade. Assim, matérias que digam respeito aos interesses públicos derivados, de natureza instrumental, devem ser solucionadas por arbitragem (inclusive para otimizar a gestão pública, posto que ao estabelecer o preço do serviço ou obras o contratante privado leva em consideração os custos que incorrerá com possíveis e futuras demandas judiciais duradouras). Por isso, decisões esporádicas e dissociadas da realidade (dir-se-iam anacrônicas), no âmbito dos órgãos incumbidos de revisar os atos administrativos, que ainda não se ativeram às modernas técnicas administrativas existentes no novo cenário que une o contratante público e o privado, deveriam rever e analisar a pertinência da arbitragem como meio idôneo de solucionar diferendos contratuais. ${ }^{56}$

A partir dos elementos apresentados, destaca-se que a atividade administrativa não se resume a formas unilaterais e impositivas, mas também a atos bilaterais que consubstanciam $m$ acordos de vontades geradores de mútuas e recíprocas obrigações. A busca de formas consensuais de solução de litígios com seus destinatários torna a Administração mais

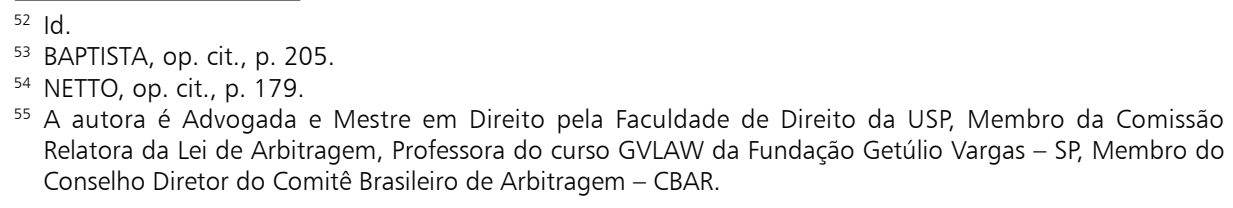

${ }^{55}$ A autora é Advogada e Mestre em Direito pela Faculdade de Direito da USP, Membro da Comissão Relatora da Lei de Arbitragem, Professora do curso GVLAW da Fundação Getúlio Vargas - SP, Membro do Conselho Diretor do Comitê Brasileiro de Arbitragem - CBAR. 
legítima e atrativa para a captação de novos colaboradores na persecução do interesse público. Reflete uma nova visão do Direito ditada pela Constituição cidadã que inaugura uma nova era no relacionamento entre a Administração Pública e os cidadãos, não mais simplesmente administrados. ${ }^{57}$ Segundo Bacellar Filho, com efeito, "um Direito Administrativo concebido para cidadãos que buscam se defender do Estado, mostra-se inadequado para proteger administrados que buscam ações positivas do Estado." ${ }^{58}$

No Direito, não deve prevalecer o excesso de conservadorismo, que impede o desenvolvimento da sociedade e, por conseguinte, da dogmática jurídica que a acompanha, tampouco o radicalismo destruidor que não assegura a continuidade das instituições. ${ }^{59}$ No dizer de Juarez Freitas, "faz-se imprescindível revisar categorias à luz das transformações paradigmáticas que conduzem ao controle mais dialógico, democrático e conciliatório, menos unilateral e preso à legalidade estrita." ${ }^{60}$ A utilização de meios consensuais de solução de conflito vem ao encontro ao reconhecimento de que o contratado é um colaborador da Administração e que a boa-fé deve presidir o contrato administrativo. Não se pode perder de vista que a tônica do dispositivo constitucional que assegura ao particular a manutenção da equação econômico-financeira durante todo o período de execução do contrato, está, sem dúvida, dirigida à preservação de um valor maior do que a disputa patrimonial em litígio: o interesse público de ver realizado o escopo contratual, sem deteriorações ou eventuais paralisações pendente de solução de controvérsias. Nesse sentido, destaca Arnold Wald que se "o direito tem a dupla finalidade de garantir tanto a justiça como a segurança, é necessário encontrar o justo equilíbrio entre as duas aspirações, sob pena de criar um mundo justo, mas inviável, ou uma sociedade eficiente, mas injusta, quando, na realidade, é preciso conciliar a justiça e a eficiência." ${ }^{\prime 1}$

Propiciar às partes um modo mais célere e especializado de solução de conflitos implica em conferir maior efetividade aos princípios gerais de Direito que norteiam a relação contratual entre a Administração e o

\footnotetext{
56 LEMES, Selma M. Ferreira. Arbitragem na Concessão de Serviços Públicos: Arbitrabilidade Objetiva, Confidencialidade ou Publicidade Processual. Disponível em: <htpp://www1.jus.com.br/doutrina/ textos.asp>. Acesso em: 22 jul. 2004.

57 BORGES, op. cit., p. 187.

58 BACELLAR FILHO, Romeu Felipe. O Novo Código Civil e o Direito Administrativo: Temas Polêmicos. Curitiba, 2004. 300 f. Tese (Obtenção do título de professor titular de direito administrativo) - Pontifícia Universidade Católica do Paraná, p. 111

59 WALD; MORAES, op. cit., p. 46.

60 FREITAS, Juarez. O Controle dos Atos Administrativos e os Princípios Fundamentais. 3. ed. rev. ampl. São Paulo: Malheiros, 2004. p. 17.
} 
particular, em especial os princípios da segurança jurídica, moralidade e da boa-fé.

\section{Considerações finais}

A associação do particular à Administração Pública, se dá de forma consensual, em regra, como resultado de um processo licitatório em que a Administração procura no mercado interessados na execução conjunta de determinada atividade, culminando-se com a celebração de um contrato administrativo. Há de se destacar que essa relação deve se assentar no respeito mútuo de interesses com vistas à consecução do interesse público. Por esses motivos, a legislação especial que regula a matéria contratual, em especial a denominada Lei de licitações - Lei $n^{\circ}$ 8.666/93, possibilitou o desenvolvimento da teoria do equilíbrio econômico-financeiro dos contratos administrativos, que garante aos contratantes a intangibilidade da equação econômico-financeira travada. A teoria ganhou reconhecimento constitucional evidenciando a importância da colaboração do particular nas atividades administrativas. A manutenção do equilíbrio econômico-financeiro, ou intangibilidade da equação financeira, apresentase como o mais legítimo dos direitos do contratado, sendo que a este respeito não divergem a doutrina.

O particular, ao contratar com a Administração, cujo objeto é passível de formar o contrato administrativo, o faz consciente de que está assumindo o papel de colaborador com o interesse geral, a partir do que deverá estar apto a suportar as alterações nos termos contratuais, caso as necessidades públicas as imponham, porém, as disposições legais o asseguram o direito à intangibilidade das cláusulas econômicas. O princípio do equilíbrio econômico-financeiro do contrato se assenta no respeito mútuo de interesses nas relações entre a Administração e o particular. Cabe à Administração atuar em seus contratos com absoluta lisura e respeito aos interesses econômicos de seu colaborador, pois não cabe ao Poder Público reduzi-los ou convertê-los em benefícios econômicos suplementares, tampouco em auferir vantagens em detrimento da outra parte, uma vez que uma das regras de interpretação das relações contratuais é que esta se faça de acordo com a presunção de lealdade e boa-fé de ambas as partes, a qual o Estado deve submissão em estrita observância ao principio da legalidade - em sentido amplo.

O argumento de que a Administração Pública não estaria autorizada, ${ }^{61}$ WALD; MORAES, op. cit., p. 46.

A \& C R. de Dir. Administrativo e Constitucional, Belo Horizonte, ano 5, n. 21, p. 99-117, jul./set. 2005 
em virtude dos princípios da indisponibilidade e da supremacia do interesse público, a renunciar ao direito de recorrer ao Judiciário para dirimir suas controvérsias, bem como, que tal atitude implicaria em violação ao princípio da legalidade, uma vez que a decisão arbitral pode, em tese, fundar-se por equidade, tem mantido a doutrina administrativista dividida. Todavia, há o reconhecimento na esfera das relações contratuais administrativas, da solução amigável de controvérsias pela arbitragem, no que diz respeito aos contratos de concessão e permissão de serviços públicos — Lei $\mathrm{n}^{\circ}$ 8.987/95 — para os serviços públicos elencados no artigo 175 da CF, que estabelece como cláusula essencial a que diz respeito ao foro e ao modo amigável de solução de divergências contratuais, aplicando-se a esses contratos administrativos também a Lei $n^{\circ}$ 8.666/93.

Destaque-se ainda que o art. 54, caput, da Lei de licitações determina a aplicação, supletiva, dos princípios da teoria geral dos contratos e das disposições de Direito privado aos contratos administrativos, representando inequívoco reconhecimento dos meios consensuais de solução de litígios. A adoção da via arbitral não implica em renuncia, pelo Estado, da jurisdição. Evidentemente, esta continua sendo um monopólio estatal. Os modos de resolução do litígio são separados e, a princípio, estanques, de tal forma que não logrando êxito na via arbitral as partes podem recorrer ao Judiciário, em estrita observância à disposição constitucional contida no art. $5^{\circ}, \mathrm{XXV}$, que garante a apreciação do Poder Judiciário de qualquer lesão ou ameaça a direito. A eleição do foro arbitral como meio consensual de solução de litígio não elimina, nem prejudica a justiça, apenas acrescenta uma alternativa ao aparelho judicial do Estado, assoberbado de trabalho e, em regra, incapaz de responder com decisões céleres e oportunas às demandas contratuais que possuam expressão patrimonial e que por isso, configuram interesses públicos disponíveis e passíveis de solução por arbitragem. Assim, é possível afirmar que a questão da juridicidade da arbitragem em contratos administrativos já foi recepcionada pelo regime jurídico administrativo.

A consensualidade já é realidade na esfera administrativa. A natureza jurídica dos contratos administrativos é, na sua essência, consensual, na medida em que somente vincula-se à Administração aquele que se interessa pelo objeto contratual e pressupõe obter um resultado financeiro deste, evidenciando que a atividade administrativa não se resume apenas formas unilaterais e impositivas. O contrato administrativo representa uma cola- 
boração recíproca, livremente assumida pelo particular e pelo Poder Público. Essa é a principal diferença entre contrato administrativo e ato administrativo, este sim, impositivo e unilateral.

A busca de formas consensuais de solução de litígios com os particulares torna a Administração mais legítima e atrativa para a captação de novos colaboradores na persecução do interesse público. Mesmo nesta nova perspectiva, o processo decisório da Administração deverá fundarse na observância dos princípios da legalidade, impessoalidade, moralidade, publicidade e eficiência, restando assim garantidas todas as conquistas obtidas pelo regime jurídico administrativo.

\section{Referências bibliográficas}

BACELlar FILHO, Romeu Felipe. O Novo Código Civil e o Direito Administrativo: Temas Polêmicos. Curitiba, 2004. 300 f. Tese (Obtenção do título de professor titular de Direito Administrativo) - Pontifícia Universidade Católica do Paraná.

BACELlAR FILHO, Romeu Felipe. Processo Administrativo Disciplinar. São Paulo: Max Limonad, 2003.

BAPTISTA, Patrícia. Transformações do Direito Administrativo. Rio de Janeiro: Renovar, 2003.

BORGES, Alice Maria Gonzáles. Valores a serem considerados no Controle Jurisdicional da Administração Pública: Segurança Jurídica - Boa-fé - Conceitos Indeterminados Interesse Público. In: Horizonte: Fórum, 2004. . Temas do Direito Administrativo Atual: Estudos e Pareceres. Belo

FREITAS, Juarez. O Controle dos Atos Administrativos e os Princípios fundamentais. 3. ed. rev., ampl. São Paulo: Malheiros, 2004.

JUSTEN FILHO, Marçal. Comentários à Lei de Licitações e Contratos Administrativos. 8. ed. São Paulo: Dialética, 2001.

LEMES, Selma M. Ferreira. Arbitragem na Concessão de Serviços Públicos: Arbitrabilidade Objetiva, Confidencialidade ou Publicidade Processual. Disponível em: < htpp://www1.jus. com.br/doutrina/textos.asp>. Acesso em: 22 jul. 2004.

MEDAUAR, Odete. O Direito Administrativo em Evolução. 2. ed. rev., atual. ampl. São Paulo: Revista dos Tribunais, 2003.

MELLO, Celso Antonio Bandeira de. Curso de Direito Administrativo. 17. ed. rev., atual. São Paulo: Malheiros, 2004.

MODESTO, Paulo. Participação Popular na Administração Pública: Mecanismos de Operacionalização. Revista Diálogo Jurídico, Salvador, v. 1, n. 7, out. 2001. Disponível em: <htpp://www. Direitopublico.com.br/sumario/asp> Acesso em: 29 jul. 2004.

MOREIRA NETO, Diogo de Figueiredo. Mutações do Direito Administrativo. 2. ed. atual. ampl. Rio de Janeiro: Renovar, 2001.

MUNIZ, Tânia Lobo. Arbitragem no Brasil e a Lei 9.307/96. Curitiba: Juruá, 1999.

NETTO, Luisa Cristina Pinto e. Interesse Público e Administração Concertada. Revista de

A \& C R. de Dir. Administrativo e Constitucional, Belo Horizonte, ano 5, n. 21, p. 99-117, jul./set. 2005 
Direito Municipal, Belo Horizonte, v. 4, n. 7, p.173-182, jan./mar. 2003.

NOBRE JÚNIOR, Edílson Pereira. O Princípio da Boa-fé e sua Aplicação no Direito Administrativo Brasileiro. Porto Alegre: Sergio Antonio Fabris, 2002.

VAZ, Isabel. Arbitragem, Licitação e Livre Concorrência. Revista de Direito Municipal, Belo Horizonte, v. 4, n. 7, p.173-182, jan./mar. 2003.

WALD, Arnold; MORAES, Luiza Rangel de et al. O Direito de Parceria e a Lei de Concessões. 2. ed. rev., atual. São Paulo: Saraiva, 2004.

Informação bibliográfica deste texto, conforme a NBR 6023:2002 da Associação Brasileira de Normas Técnicas (ABNT):

SCHWANKA, Cristiane. O princípio do equilíbrio econômico-financeiro em face das transformações do regime jurídico administrativo. A $\mathcal{E}^{2}$ C Revista de Direito Administrativo e Constitucional, Belo Horizonte, ano 5, n. 21, p. 99-117, jul./set. 2005. 